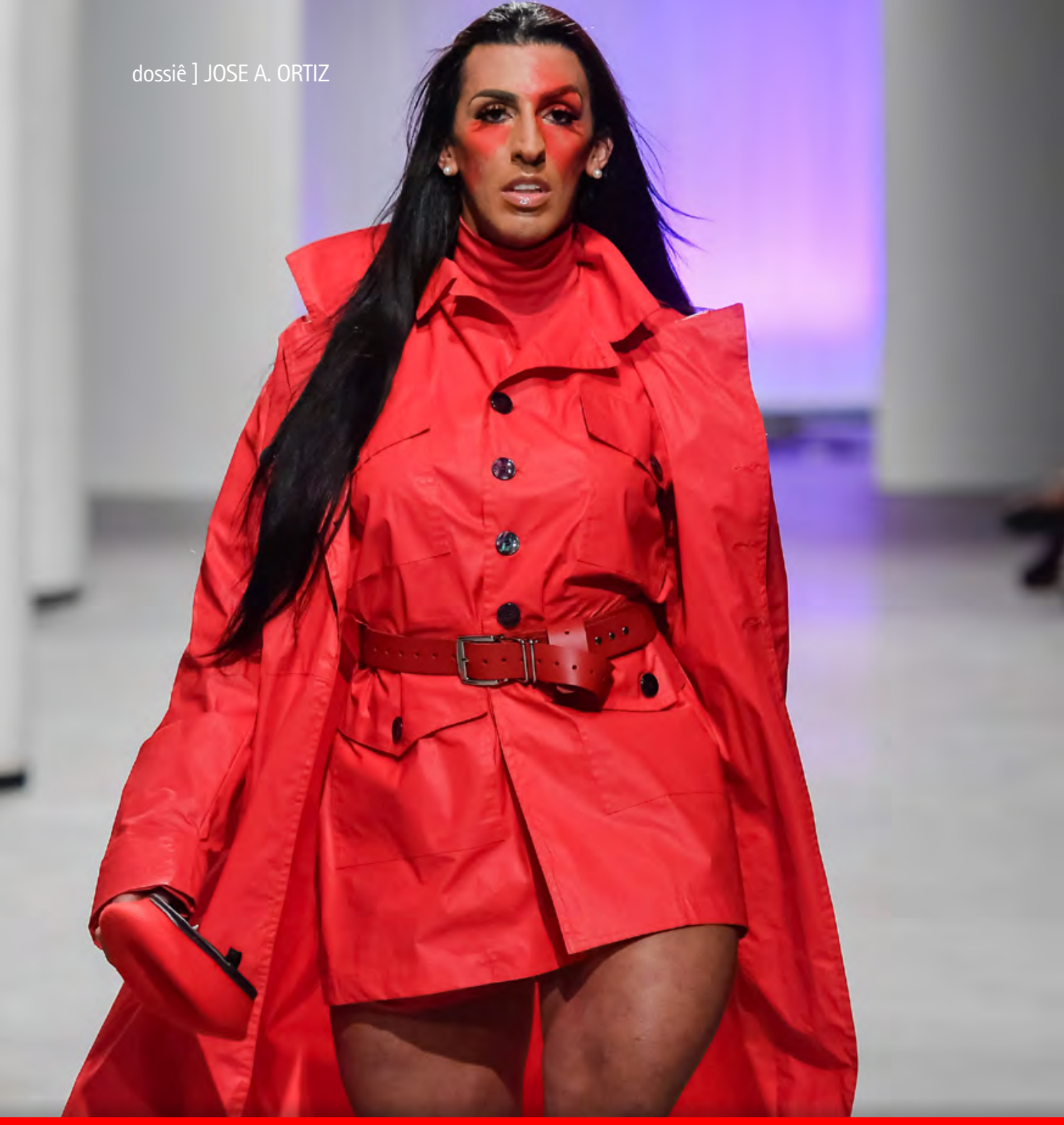

\title{
Dolor y muerte en la indumentaria española. Vestir de luto a finales del siglo XIX
}

Dor e morte na indumentária espanhola. Vestir-se de luto no fim do século XIX

Pain and death in Spanish fashion. Mourning dress at the end of the 19th century 
[JOSE A. ORTIZ]

Doutor em História da Arte. Professor na Universitat Autònoma de Barcelona (UAB)

E-mail: joseaortiz50@yahoo.es

[resumen] La indumentaria de luto es una expresión externa de dolor ante la pérdida de un ser querido. La moda se convierte en una estrategia comunicativa durante este proceso de duelo, y durante los períodos históricos, las reglas fueron marcadas y estipuladas. Para abordar este tema, queremos analizar dos secciones en nuestra investigación. En primer lugar, abordar el último funeral real y el período de luto a finales del siglo XIX español con el rey Alfonso XII y la reina María Cristina como protagonistas. En segundo lugar, comentar las referencias de prensa que se publicaron y analizar las revistas de moda que nos permiten desarrollar el protocolo de luto a seguir para estas décadas en los territorios españoles.

\section{[palabras clave]}

\section{dolor; luto; moda; España; siglo XIX.} da perda de um ser querido. A moda se converte em uma estratégia comunicativa durante esse processo de dor e, durante os períodos históricos, as regras foram marcadas e estipuladas. Para abordar esse tema, queremos analisar dois recortes em nossa pesquisa. Em primeiro lugar, abordar 0 último funeral real e subsequente período de luto, ao fim do século XIX, com o rei Alfonso XII e a rainha Maria Cristina como protagonistas. Em segundo lugar, comentar as informações que eram publicadas na imprensa e analisar as revistas de moda que nos permitem estabelecer o protocolo de luto a ser seguido naquelas décadas nos territórios espanhóis.

[palavras-chave] dor; luto; moda; Espanha; século XIX.

[abstract] Mourning dress is an external expression of pain in front of the loss of a beloved relative. Fashion becomes a communicative strategy during this grieving process, and during historical periods the rules were marked and stipulated. In order to approach this topic, we aim to discuss two main parts for our research. Firstly, we introduce the last Royal Funeral and the subsequent mourning period in the late Spanish $19^{\text {th }}$ century with King Alfonso XII and Queen Maria Cristina as main characters. Secondly, we comment on the press references which were published and analyze the fashion magazines which allow us to develop the mourning protocol for these decades in Spanish territories.

[keywords] pain; mourning; fashion; Spain; $19^{\text {th }}$ century. 
El poder comunicativo de la moda es una de las bases del lenguaje que la indumentaria nos aporta. Nuestro estado de ánimo, nuestra ideología, nuestro querer formar parte de la sociedad o romper radicalmente con ella, son algunas de las ideas asociadas que los estudios de semiótica y sociología de la moda han abordado en los últimos años. Dice Squicciarino citando a Baudrillard que:

Para poder convertirse en objeto de consumo, los bienes en general y los de la moda en particular tienen que convertirse en signos, ya que el consumo ha dejado de definirse como práctica funcional de los objetos para ser un sistema de comunicación y de intercambio, un código de signos que se emiten, se reciben y se renuevan constantemente, como un lenguaje (SQUICCIARINO, 2012, p. 179, énfasis del autor).

El vestido, en cuanto acto comunicativo, también ha sido un referente como expresión del dolor ante la pérdida de un ser querido: vestir de luto hace visible las emociones más profundas de nuestra alma. Lejos quedan los motivos de protección, pudor o adorno del vestido que comenta Flügel, para acercarnos a una narración del yo corporal a través de las prendas (FLÜGEL, 2015). Sobre el luto queremos reflexionar en este trabajo abordando el caso de la cultura española a finales del siglo XIX. Para aproximarnos al tema de investigación y al periodo proponemos una doble mirada, en primer lugar acercarnos al último referente de muerte real y luto áulico tras la pérdida del rey Alfonso XII; y en segundo lugar, un análisis de la prensa escrita que adoctrina sobre el luto y el uso social del mismo. Este binomio, muerte real y prensa escrita, nos ofrece un marco visual y conceptual para entender como en el último cuarto del siglo XIX la sociedad se enfrenta a la muerte. Las pautas de luto de la monarquía se reflejan en los diferentes estratos de la sociedad y es a través de las revistas que las lectoras de clase alta y media pueden acceder a ellas.

\section{Sobre la conceptualización del luto y del duelo}

Luto y duelo no significan lo mismo. El duelo se define como el proceso psíquico de elaboración del dolor de la muerte. El duelo se vuelve "necesario para poder continuar viviendo, para separarse de la persona perdida conservando lazos diferentes con ella y para reencontrar la libertad del funcionamiento psíquico" (GÓMEZ SANCHO, 2007, p. 30). El luto en cambio es el signo exterior del duelo a través de las ropas, adornos y otros objetos (DI NOLA, 2006). El luto, o tempus lugendi, es un compendio de ritos y símbolos sociales para encauzar adecuadamente el sentimiento de pérdida, o el dolussi utilizamos la noción en latín. La historia de la indumentaria nos aporta una perspectiva amplia para analizar las formas históricas del 
luto y aquellos elementos definitorios en las diferentes sociedades. Lou Taylor se hacía eco de algunos conceptos sobre la indumentaria de luto que desarrollamos en nuestro texto:

Mourning clothes served several purposes: they indicated the piety and chastity of the wearer; they denoted the wealth and social status of the bereaved family. As royal funeral etiquette filtered slowly down through the class system, widows became a perfect shop window for an impressive display of social expertise. From the Renaissance onwards the sumptuary laws governing mourning dress in general, and widows' in particular, grew into an intricate labyrinth covering choice of fabric, color, cut and accessories. Widows' clothes became a status symbol (TAYLOR, 2009, p. 65).

La indumentaria de luto es un símbolo personal del dolor con una proyección social regulada por las sociedades y una codificación que ha sido modificada a lo largo de la historia. Vestirse de luto es una necesidad, pero la forma de llevarla a cabo ha sido la que varía entre épocas medievales y modernas ${ }^{1}$. La moda luctuosa es el canal a través del cual nuestro llanI5 ] to se hace presente cumpliendo las normas estipuladas en cada contexto histórico y social, citando una vez más a Flügel y su aproximación a la significación social del vestido (FLÜGEL, 2015). Centrarnos en el ocaso del siglo XIX nos aporta una interesante relación entre el luto oficial por la muerte del monarca y como la sociedad se hace eco del mismo a través de la prensa y difunde los códigos y normas sociales para vestirse correctamente, acotando el tema a un lugar y a un tiempo determinado. Las lectoras pertenecen a estas clases sociales altas y medias que quieren ser reflejo de las aristocráticas. Con los centros de poder político y económico ligados a las grandes ciudades, la difusión en papel de las ideas de la moda se convierte en el mejor sistema para llegar a diferentes lugares del reino y a diferentes partes de la sociedad ávidas de emular la etiqueta de la Corte y la elegancia de las ciudades decimonónicas.

\section{El luto real en el ocaso decimonónico}

Alfonso XIl, nacido el 28 de noviembre de 1857, fallece el 25 de noviembre de 1885. Tras unos duros meses convaleciente por la tuberculosis, se apaga la llama de la vida en él y se inicia un nuevo período político bajo las riendas de su segunda esposa, la reina María Cristina (1858-1929), hasta la mayoria de edad de su sucesor Alfonso XIII (1886-1941). Con Alfonso XII nos encontramos ante el último ejemplo de funeral a un monarca en la cultura española del siglo XIX. El 12 de Diciembre se celebraron en el templo de San Francisco el Grande las exequias fúnebres de Estado (VARELA, 1990, 
p. 192-193). La prensa se hace eco de la noticia y merece especial atención el reportaje con grabados que La llustración Española y Americana dedica a los funerales del monarca, plasmando el cortejo fúnebre y las diferentes etapas del protocolo regio (LOS FUNERALES, 1885, p. 229-339).

Al traspasar Alfonso XII una inusual expresión de dolor se lleva a cabo. Gritos destemplados, articulación de frases incoherentes, desmayos y suministro de antiespasmódicos, son algunas de las actitudes de los familiares del monarca ante la pérdida: "El sentimiento estalla incontenible a la hora de la muerte. Si, pocos años hacía, la Iglesia recomendaba un llanto moderado por los difuntos [...] ahora hasta los sacerdotes tiñen de melancolía sus oraciones fúnebres" (VARELA, 1990, p. 166). Este estado de dolor es la que plasma la indumentaria adoptada por la reina viuda, siguiendo la tradición monárquica con ejemplos paradigmáticos para los siglos anteriores con Juana de Austria o con Mariana de Austria (CALVO POYATO, 2002; LLORENTE, 2006; MARTÍNEZ-BURGOS, 2008; ORTIZ GARCÍA, 2013).

La reina Maria Cristina adopta la indumentaria de luto y en las imágenes relacionadas con su presencia ante el cuerpo fallecido así la observamos. El valenciano Juan Antonio Benlliure y Gil (1860-1930) así lo pintó en su obra de 1887, Muerte de don Alfonso XII (El último beso) del Museo Nacional del Prado de Madrid, depositada en el Palacio de Pedralbes de Barcelona ${ }^{2}$. Entre los personajes se hallan el confesor del rey, el cardenal Benavides, y el duque de Montpensier, entre otras personalidades. Junto a la cabecera permanece su viuda de luto enjugándose el llanto con un pañuelo. Junto a ella, su hija mayor, la infanta María de las Mercedes, y al otro lado, la pequeña infanta María Teresa, que da el último beso a su padre. La reina viste un traje sobrio negro, con alguna decoración bordada, pero respetando la falta de brillo en los tejidos y el control de exceso decorativo que se exigía en la etiqueta luctuosa.

En el período de su regencia mantiene el luto en los retratos oficiales que de ella se realizan, ya sean pictóricos o fotografiados. José Manuel Laredo y Ordoñez (1840-1896) plasma en el mismo año 1887 un retrato de la regente ofreciéndonos una imagen muy nítida de la indumentaria de viuda. María Cristina de Habsburgo-Lorena del Museo Nacional del Prado depositado en el Ministerio de Agricultura de Madrid, presenta la corona y los símbolos regios del poder que otorgan el estatus de regente a la retratada ${ }^{3}$. Vistiendo vestido negro de manga tres cuartos con algunas decoraciones bordadas en cuello y mangas, resalta el tocado y velo, con tiara de perlas negras. Al riguroso negro del segundo año de viudedad, se añade joyería en oro y perlas blancas en los brazaletes, junto al blanco del borde inferior de la falda de origen inglés. 
En cambio, en retratos datados en los años noventa del siglo XIX se observa la evolución del luto a estadios de medio luto. El barcelonés Antoni Caba (1838-1907) en 1890 realiza el lienzo Retrato de la reina regente María Cristina de Habsburgo conservado en la Real Academia Catalana de Bellas Artes de Sant Jordi de Barcelona, con estudio del mismo conservado en el Museu Nacional d'Art de Catalunya de Barcelona ${ }^{4}$. En esta obra la joyería hace su irrupción decorando cabeza, cuello y brazos. El tejido del vestido, plasmado con gran acierto, presenta brillo, y la elegancia del corte se utiliza para dejar caer la cola de la falda ante los pies y escalinata del estrado en el que se encuentra la madre con su hijo en brazos. Viuda, madre y regente son los conceptos simbólicos que Caba exalta añadiendo el león, símbolo de poder monárquico. En cierta manera, la pintura expresa el poder simbólico de la regente a través del futuro rey. El cuerpo de Maria Cristina es un cuerpo físico dotado de funciones institucionales pero desprovisto de su función previa, en tanto que esposa, tras fallecer su marido, nos hallamos con el concepto de la dislocación del cuerpo de la reina viuda: "De hecho, convertirse en reina viuda suponía una dislocación del sistema simbólico de los dos cuerpos de la reina, ya que el cuerpo físico sobrevivía a las funciones del cuerpo institucional, generando un desajuste" (GARCÍA BARRANCO, 2008, p. 51).

En el retrato María Cristina de Habsburgo con su hijo Alfonso XIII de José Martínez Bueno y Vilches del año 1896, del Museo Nacional del Prado depositado en el Ayuntamiento de La Orotava, el vestido deja al descubierto los hombros, el tejido ya presenta brillo y un tratamiento que ensalza el negro ${ }^{5}$. El velo de viuda se modifica por una tiara de oro que se acompaña con broche y brazaletes de este material sobre los brazos cubiertos con guantes blancos. El cuerpo descubierto, los materiales seleccionados para el vestido y la ornamentación personal nos trasladan a las diferentes fases de luto, como el medio luto, que manteniendo el negro permite una ampliación de las posibilidades estéticas, tal y como analizaremos posteriormente en las revistas de moda del periodo.

De las imágenes de María Cristina con Alfonso XIII, destaca la fotografía de Barcia y Viet, fotógrafos de Madrid, conservada en el Fondo Fotográfico de la Universidad de Navarra (referencia UNAV20110007577). En ella la reina viste riguroso luto con tejidos mate y un velo largo que surge de una toca. De espaldas nos permite apreciar la caída natural de la tela que contrasta con el blanco puro de la indumentaria de futuro rey en su más tierna infancia (figura 1). 
Figura 1. Retrato fotográfico de María Cristina con Alfonso XIII

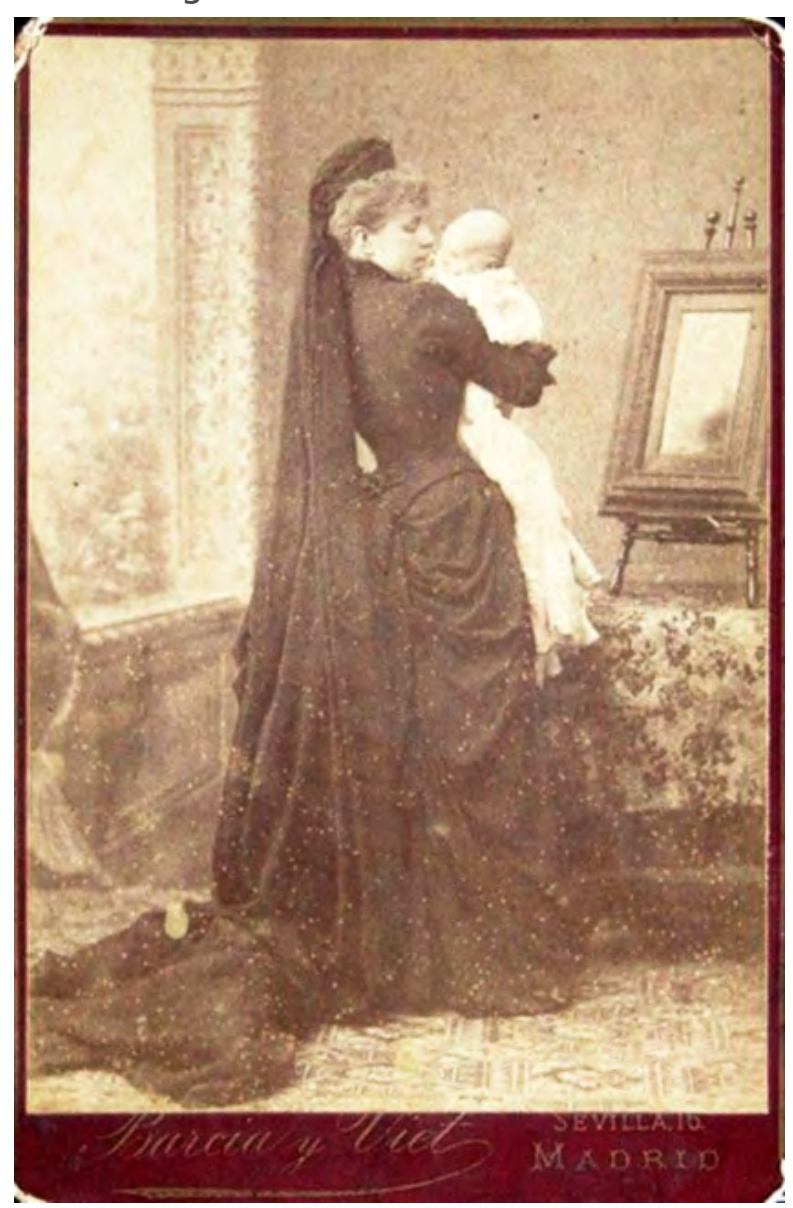

Fonte: BARCIA Y VIET. María Cristina con Alfonso XIII. Finales del siglo XIX. Fondo Fotográfico de la Universidad de Navarra, (CCO 1.0).

Su poder pasaba por ser la madre del descendiente del poder áulico, y como otras reinas viudas de la historia española, el luto marca su respeto y su posición social ante la pérdida de su esposo y la imagen que de ella se evoca en las apariciones públicas. Un ejemplo claro es la pintura del Fondo Histórico del Senado de España. Los autores, Francisco Jover Casanova (1836-1890) y Joaquín Sorolla y Bastida (1863-1923), realizan en 1897 la obra que lleva por título Jura de la Constitución por S. M. la Reina Regente Doña María Cristina (figura 2). El solemne acto de juramento tuvo lugar el 30 de diciembre de 1885 y ante los presentes en pie, según rige el protocolo, la viuda se convierte en regente. Las damas y la reina visten riguroso luto, asi como sus hijas que también están presentes en la escena ataviadas con la indumentaria apropiada. Maria Cristina lleva el tocado que se observa en las representaciones comentadas anteriormente y señalamos el tamaño de la cola de la falda que reposa sobre el asiento, otro elemento distintivo de los patrones seleccionados para su armario de luto siguiendo la moda imperante (figura 3). 
Figura 2. Jura de la Constitución por S.M. la Reina Regente doña María

\section{Cristina}

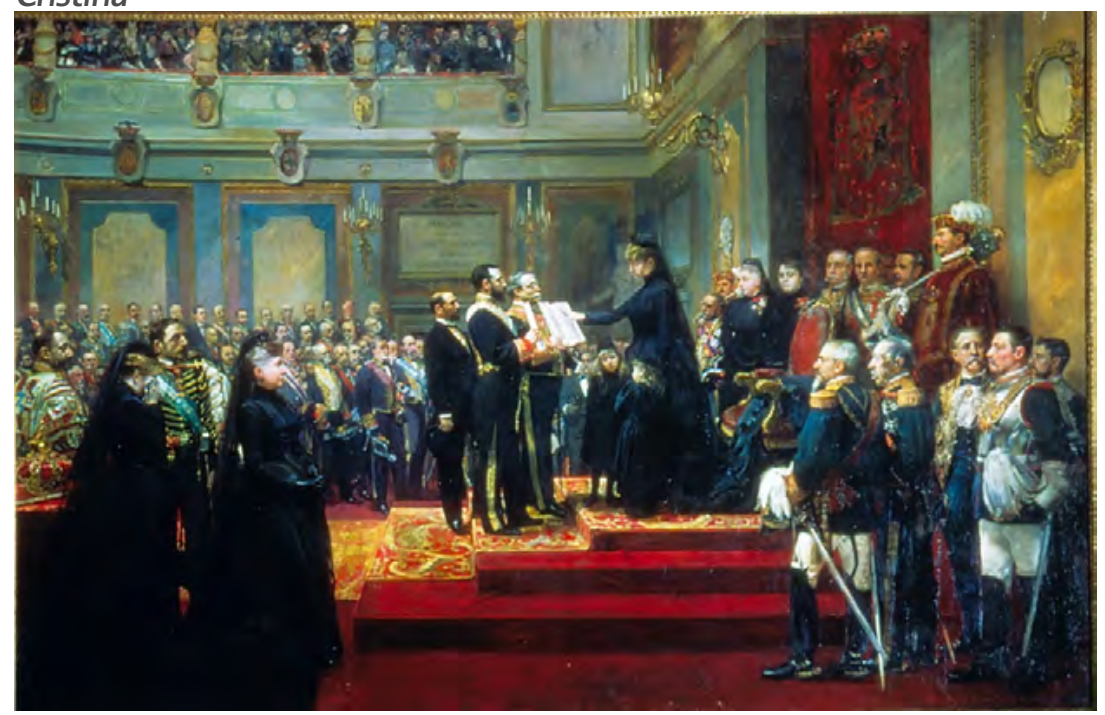

Fonte: SOROLLA Y BASTIDA, Joaquín. Jura de la Constitución por S.M. la Reina Regente doña María Cristina. 1897. Fondo del Patrimonio Histórico-Artístico del Senado, España. Autor de la fotografía: "Fotografía Oronoz".

I9 ] Figura 3. Jura de la Constitución por S.M. la Reina Regente doña María Cristina, detalle

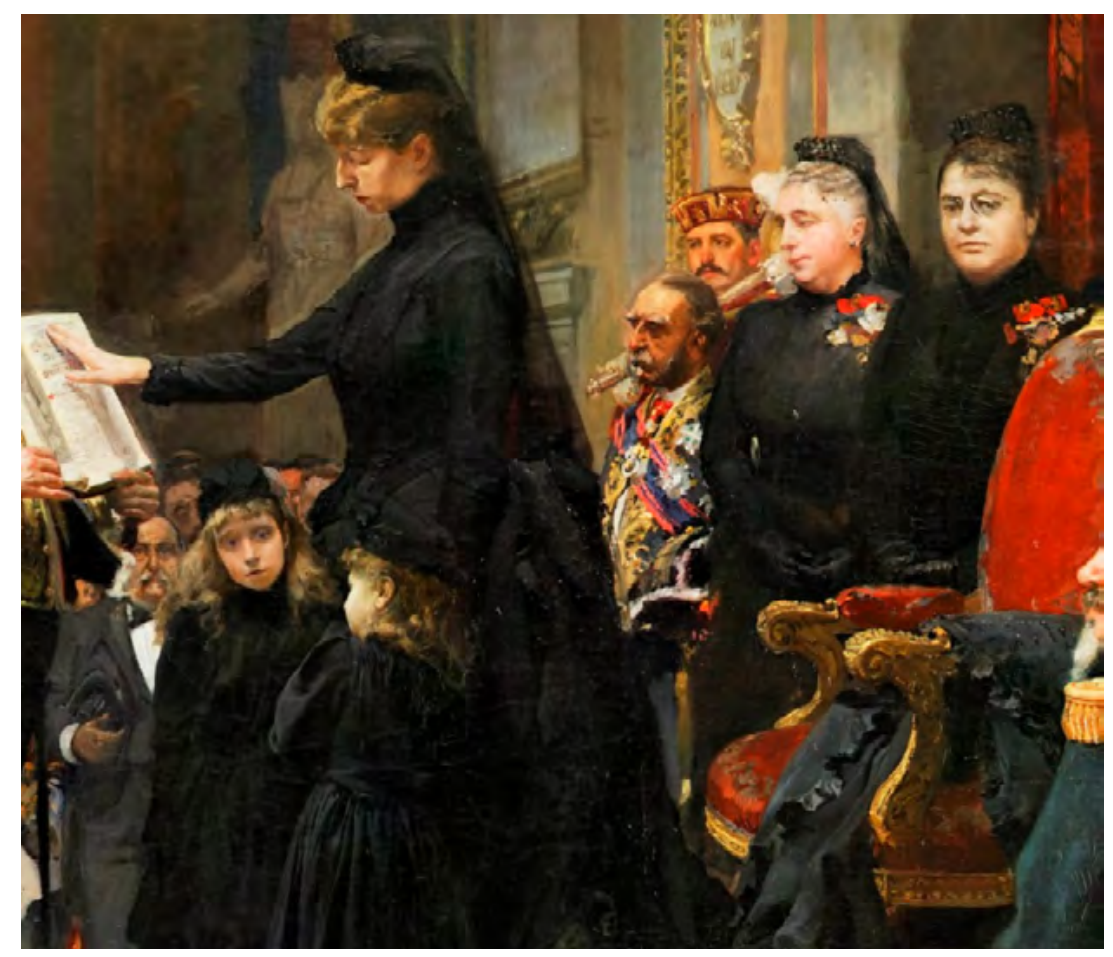

Fonte: SOROLLA Y BASTIDA, Joaquín. Jura de la Constitución por S.M. la Reina Regente doña María Cristina. 1897. Fondo del Patrimonio Histórico-Artístico del Senado, España. Autor de la fotografía: "Fotografía Oronoz". 
La ciudadanía también expresa a través del luto la pérdida. La prensa recoge en el mes de diciembre testimonios en esta línea:

\begin{abstract}
Así, se le ha llorado y se le llora lo mismo en los lujosos palacios del magnate que en la humilde vivienda del obrero; así visten luto por él los que habian apreciado de cerca sus relevantes cualidades privadas, y aquellos que sólo desde lejos pudieron juzgar sus relevantes virtudes y sus gloriosos hechos (MARQUÉS DE VALLE-ALEGRE, 1885, p. 358).
\end{abstract}

Cuando pasa el primer aniversario del fallecimiento, la sociedad recupera sus actividades que habian sido cesadas por el luto oficial. El Correo de la Moda así lo narra:

Cumplido el año de luto por nuestro malogrado Rey don Alfonso, luto guardado con un rigor poco común en las cortes palatinas, los salones empiezan a dar señales de vida y los propósitos que anima a la juventud aristocrática, son desquitar en el presente la privación de bailes y fiestas del invierno anterior: varias son ya las damas de nuestra buena sociedad que han señalado días para recibir, unas por la tarde, otras por la noche, y se citan varios salones donde se bailará: los trajes, pues, de salón y de baile, reclaman nuestra atención (HERNANDO, 1886, p. 353).

La codificación y la difusión social del luto a través de la prensa de moda del último cuarto del siglo XIX

Las representaciones de Maria Cristina nos han permitido observar un ejemplo concreto de expresión de dolor a través de la indumentaria de luto. La reina viuda se convierte, con la imagen que de ella se proyecta, en el ejemplo a seguir para las mujeres. El vestido de luto la codifica como regente pero también ensalza el papel de la mujer tras la pérdida de su marido: en ella se pueden reflejar aquellas que se encuentran en la misma situación familiar. Esta actitud la podemos relacionar con otros casos europeos, citando a la Reina Victoria (1819-1901) en el Reino Unido. Casada con el Príncipe Alberto en 1840, se queda viuda en 1861 con 42 años. Permaneció de luto riguroso por tres años y de medio luto el resto de su vida, 40 años. Las mujeres de la época victoriana siguieron el ejemplo de la Reina y se elaboraron estrictas reglas de etiqueta concernientes a la vestimenta del luto y al comportamiento durante este periodo ${ }^{6}$. Resulta interesante esta comparativa, cercana en época, que nos permite reflexionar sobre la importancia de las actitudes de las monarcas para la difusión de ciertos aspectos de la moda, en este caso la indumentaria de luto, entre la sociedad. Es interesante destacar como las relaciones entre familias reales europeas son constantes y se crea mucha permeabilidad de las 
costumbres, teniendo en cuenta que la nieta de la Reina Victoria, Victoria Eugenia de Battenberg (1887-1969) será la futura esposa de Alfonso XIII, es decir, nuera de la Reina Maria Cristina.

La prensa escrita será el mejor medio a través del cual estos conceptos se transmiten de las capas más altas de la sociedad a la realidad del día a día cotidiano de las clases altas y medias, así lo citábamos en el extracto anterior de El Correo de la Moda que se refiere a la recuperación de las festividades tras el luto real por parte de "las damas de nuestra buena sociedad" (HERNANDO, 1886a, p. 353). La monarquía representa la cúspide de la pirámide social y a ella se quiere asimilar el pueblo. Las actitudes regias se transmiten en los grabados y artículos que aparecen en las revistas de moda que empiezan a proliferar en España entre los años veinte y treinta del siglo XIX (GONZÁLEZ DíEZ; PÉREZ CUADRADO, 2009).

En el siglo XIX y XX la prensa de moda tendrá un papel fundamental en la codificación de los signos del luto aplicados a la indumentaria. No tan sólo eran las revistas, también las boutiques como la Maison de Deuil en Londres, la Grande Maison de Deuil en Bruselas o la Grand Maison du Noir en Paris, las que marcan la etiqueta y el negocio específico del duelo en el contexto del sistema moderno de la moda:

Mourning dress did, however, significantly influence modern processes of garment manufacture, retailing, and consumption. The need for a rapidity of supply helped found department stores and encouraged the wholesale manufacture of women's wear. It enhanced the commercial implementation of the use of sewing machines and early forms of mail order. Mourning etiquette also contributed to the development of early forms of plastic used in imitation of jet jewelry, and finally, the careful niche marketing of mourning dress contributed to the development of modern mass-advertising techniques (TAYLOR, 2010, p. 520).

"El luto es una cuestión de etiqueta más que de emoción" nos anuncia La Moda Elegante en 1870. Apunta el artículo sobre la mutabilidad de la moda en relación al luto:

Créese generalmente que las reglas del luto y del alivio de luto son inmutables, y que no tienen, por consecuencia, ningún lazo ni relación con la moda, mudable por gusto y por esencia: esto no es enteramente exacto. Cierto es que la duración del luto y del alivio de luto sigue siendo la misma, adaptándose a los diversos grados de parentesco; pero también es verdad que el 
espíritu o carácter del luto no es el mismo siempre, y que sufre algunas mudanzas, debidas a los excesos de la moda (VIZCONDESA DE CASTELFIDO, 1870, p. 215-216).

Así pues, luto y medio luto o alivio de luto deben de ser considerados en función de la consanguineidad de las pérdidas: entre 12 y 18 meses para los padres, entre 18 y 24 meses para los maridos o entre 6 y 12 meses para los hermanos y los tíos. Esta publicación, en su rúbrica de "Prácticas sociales" firmada por Mario Halka, para el 30 de mayo de 1885 nos ofrece una visión de las normas que se deben seguir en el momento de un fallecimiento. Destaca la explicación que hace sobre el dolor en función de las clases sociales, aportándonos un contexto social para finales del siglo XIX en relación al tema que tratamos:

Conforme va subiéndose en la sociedad, desde sus clases inferiores hasta las más elevadas, vase notando como la manifestación del dolor es en cada una de ellas reflejo de sus principios religiosos o de su educación intelectual. En las masas ínfimas, el pesar es explosivo y ruidoso; alli, aunque hay fe en las verdades eternas, no hay respeto para las conveniencias sociales. No comprenden las desgracias extraordinarias sin extraordinarios alaridos, y experimentan mucho mayor consuelo al envolver un "imadre mía!" entre gritos que estremezcan el aire, que si desde el fondo de su corazón lo repitiesen enviando toda la voluntad de su vida en una invocación muda, pero delirante (HALKA, 1885, p. 158).

Una manifestación exacerbada del dolor se considera poco decorosa y propia de unos estratos sociales bajos. El dolor ante la pérdida debe darse con mesura, con contención y pensando en las creencias religiosas que hablan de un más allá. A pesar de ello, el dolor es humano y así nos lo describe el autor:

Fijándose ya en las esferas en que los impulsos están contenidos por la consideración del efecto que pueden producir en el que los siente y en el que los presencia, se advierte que, allí donde se reúne, al par que la firme y religiosa creencia de que el que muere en la gracias de Dios va a esperarnos en otra mejor vida, la triste seguridad de que sólo muy contadas personas nos acompañan en el sentimiento; alli, decimos, se manifiesta éste silencioso y resignado (...) De todos modos, la pérdida de un ser querido aterra y apesadumbra. En cuanto a la sorpresa que produce, es puramente humana, pues no debiera sorprendernos lo que estamos esperando (HALKA, 1885, p. 158). 
Pocas revistas de moda tratan los conceptos de dolor y religiosidad como desarrolla este fragmento. Al hablarnos de esferas sociales se marca una distinción entre clases que nos marca al público lector: las lectoras pertenecen a una clase alta y media que debe alejarse de las fórmulas exacerbadas de dolor de los estratos más bajos de la sociedad. A su aportación teórica, e incluso sociológica, se añaden las consignas que se deben seguir, tales como, los nueve días de luto en los que la familia no recibe, situando una mesa a la entrada que lo especifique y poniendo "un gran pliego de papel, tintero con varias plumas y una bandeja para las tarjetas". El texto va más allá refiriéndose a las actitudes durante el novenario ${ }^{8}$, especialmente las visitas que buscan no consolar a los familiares, sino más bien conocer detalles truculentos de lo acontecido:

Hay, sin embargo, familias que prefieren recibir a todo el mundo, y gastar en aquel aturdimiento, en aquel indice de preguntas indiscretas, vanas y hasta crueles con que se acosa a la infortunada viuda o huérfana en las visitas del novenario, una parte de lo acerbo del dolor que les atormenta. En esos días no son los que más preguntan los que mayormente se interesan. Así como el deseo de saber ciertos detalles, para llorarlos, halaga más bien a aquel de quien se inquieren, la curiosidad de conocerlos por el gusto de referirlos en otros círculos es casi una ofensa en esos momentos tan angustiosos. La delicadeza del sentimiento prescribe dejar para más adelante todas aquellas insinuaciones que han de herir sobre la llaga reciente, $y, \sin q u e$ la conversación sea tan chispeante que forme brusco contraste con la situación presente, debe procurarse desviarla un tanto del principal objeto. Será dar prueba de poco tacto el ofenderse por no ser recibido en los primeros momentos de una desgracia (HALKA, 1885, p. 158).

Ante la necesidad de conocer las actitudes adecuadas y queriendo conocer las reglas que marca la etiqueta, hallamos en prensa especificaciones de los protocolos del luto, ya sean cartas del lector o de la lectora, 0 artículos sobre el tema. En 1872 una joven viuda preguntaba en El Correo de la Moda las reglas para el período de luto. La respuesta la veta de asistir a cualquier evento social durante el primer año:

El consejo que $V$. me pide es muy delicado, porque ante todo hay que respetar las conveniencias sociales. Ir al teatro 0 a cualquier parte antes de terminar el año de luto, sería mal visto. Sólo puede V. permitirse algunas visitas de confianza (CORRESPONDENCIA, 1876, p. 336).

Esta es la norma más difundida: no asistir a actos durante los períodos de luto riguroso. Sólo visitas de amistades íntimas son adecuadas y bien vistas: 
Durante el luto riguroso no se harán visitas de cumplido, ni se asistirá a comidas, teatros ni reuniones. Podrá verse a las amigas de mayor confianza y comer a las mesas donde no se invite por papeleta. No se darán comidas, ni reuniones, ni se recibirá semanalmente; pero, sin tal carácter, puede tenerse la libertad a ser visitados por sus amigos. No se envian tampoco tarjetas de felicitación (HALKA, 1885, p. 159).

A las adecuadas premisas protocolarias debemos añadir las especificaciones sobre la indumentaria. El citado Mario Halka asi lo expresaba en relación a otras fórmulas culturales:

El traje de luto, por más que sea severo, puede ser muy esmerado. No existiendo entre nosotros la ley hebrea que impone a los hijos la obligación de dejarse crecer la barba durante el mes que sigue a la muerte de los padres, ni la de los orientales, que rompen sus vestidos y conceptúan la profundidad del dolor por la dimensión de cada uno de sus jirones, el descuidar el aseo del cuerpo porque el alma esté contristada es una consecuencia incomprensible y que rechazan las personas sensatas (HALKA, 1885, p. 159).

Tomemos un ejemplo que especifica dos modelos de indumentaria de luto, luto riguroso y medio luto. Los dos figurines ilustran el texto sin ser un ejemplo específico para su ejecución, como es el caso de figurines más detallados que la misma publicación acostumbra a ofrecer a sus lectoras (figura 4). Para el primer estado de luto se aconseja este patrón genérico:

He aqui un modelo de gran severidad, como lo exige un luto de viuda. El vestido va cubierto de crespón inglés hasta 20 centímetros de la cintura. En el cuerpo un corselillo de crespón, con adornos de crespón en las mangas, y la capota cubierta del velo largo de crespón. Enagua de merino o de cachemir negro, adornada con galones de lana o con un bordado hecho sobre la misma tela. Medias negras y botinas de tela para el verano, o de cabritilla para el invierno. Los pendientes, broches y pulseras son de madera endurecida, y los pañuelos llevan una ancha cenefa negra (VIZCONDESA DE CASTELFIDO, 1889, p. 352). 
Figura 4. Modelos de indumentaria de luto, luto riguroso y medio luto La Moda Elegante, 22/11/1889

งระ

ja Moda fílegaxte, Pequódico de las pamitias.

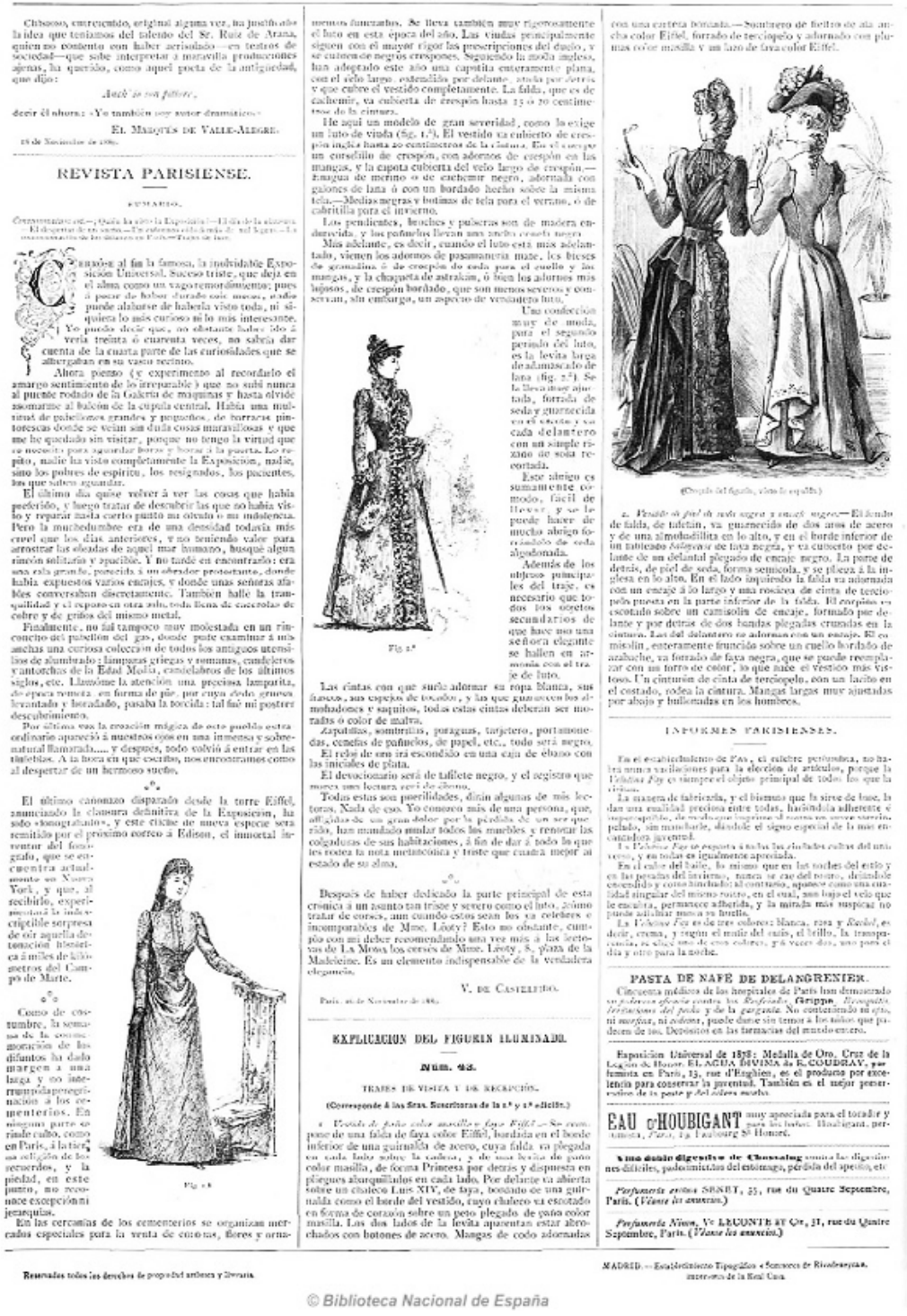

Fonte: LA MODA ELEGANTE, 22 nov. 1889, p. 352. Fondo de la Biblioteca Nacional de España, (CC BY-SA 4.0).

Más adelante, es decir, cuando el luto está más adelantado, vienen los adornos de pasamanería mate, de crespón de seda, de astracán u otros materiales menos severos que conservan la etiqueta de luto. En el segundo período de luto, una propuesta es la siguiente:

Una confección muy de moda, para el segundo periodo del luto, es la levita larga de adamascado de lana. Se la lleva muy ajusta$\mathrm{da}$, forrada de seda y guarnecida en el escote y en cada delantero con un simple rizado de seda recortada [...] Además de los 
objetos principales del traje, es necesario que todos los objetos secundarios de que hace uso una señora elegante se hallen en armonía con el traje de luto. Las cintas con que suele adornar su ropa blanca, sus frascos, sus espejos de tocador, y las que guarnecen los almohadones y saquitos, todas estas cintas deberán ser moradas o color de malva. Zapatillas, sombrillas, paraguas, tarjetero, portamonedas, cenefas de pañuelos, de papel, etc., todo será negro. El reloj de oro irá escondido en una caja de ébano con las iniciales de plata. El devocionario será de tafilete negro, y el registro que marca una lectura será de ébano" (VIZCONDESA DE CASTELFIDO, 1889, p. 352).

La especificación de los complementos, incluso de los marcapáginas para la lectura, nos muestra la rigidez del luto y la importancia de la visibilidad del dolor a través de la moda. Para el hombre, el luto era menos estricto: colores oscuros, botones negros y brazalete negro en el brazo eran los elementos más habituales. Pueden parecer estas especificaciones exageradas, pero se defienden como un sistema de expresión del alma afligida:

Todas estas son puerilidades, dirán algunas de mis lectoras. Nada de eso. Yo conozco más de una persona, que, afligidas de un gran dolor por la pérdida de un ser querido, han mandado mudar todos los muebles y renovar las colgaduras de sus habitaciones, a fin de dar a todo lo que les rodea la nota melancólica y triste que cuadra mejor al estado de su alma (VIZCONDESA DE CASTELFID0, 1889, p. 352).

En lengua catalana, La II/lustració Catalana, nos ofrece un muestrario de tejidos adecuados a cada fase de duelo. En el primer periodo de luto, tejidos mate como son el crep, la lana o el astracán. La madera negra o el azabache se aconsejan para la joyería. En la segunda fase de duelo, la bayeta y la franela con bordados y guipur, acompañados de sombreros con plumas negras y flores. En el último periodo son la seda, el terciopelo, las lentejuelas y el encaje, algunos de los materiales brillantes aceptados. Se insiste, además, en la idea presentada anteriormente: las restricciones en las actividades sociales como el teatro o las visitas (ROSAURA, 1905).

Las ilustraciones de figurines de luto son un material de estudio de primer orden para el tema presentado. La Moda Elegante propone en 1874 un traje de medio luto sencillo o dos prendas usando cachemir y volantes que añaden sofisticación, brillo y movimiento al simple vestido negro (Traje de medio luto, La Moda Elegante, 30/07/1874, p. 228 y Traje 
de luto, La Moda Elegante, 30/10/1874, p. 331). La silueta de la época se adapta al luto riguroso o al alivio de luto. Seda y lana, guipur y volantes, es la propuesta de La Moda Elegante en 1875 para el traje de alivio de luto 0 ante la pérdida de un primo (Traje para alivio de luto, La Moda Elegante, 22/05/1875, p. 145-146). La imagen se completa con la descripción que marca el uso y la materialidad del conjunto. Podemos leer en referencia a la silueta de 1875:

Este traje puede llevarse para luto de primo o tío, o después de los meses de un luto riguroso. Falda de tela de lana y seda, adornada en el bajo con un volante a pliegues gruesos y bieses de la misma tela dispuestos de la manera siguiente: un bies ancho, dos más estrechos y otro tan ancho como el primero. Túnica de la misma tela, listada al través hasta las costuras de lado, con guipur de lana y galones de lana y seda. Las mismas guipures y los mismos galones cambian de disposición en los costados, como lo indica el dibujo. La túnica va recogida sin pouff detrás, bajo un lazo de faya. Corpiño de tela de lana y seda adornado con galones y guipures, y lazos de faya en el delantero. Mangas de codo, con guipur y galones en la parte inferior. Sombreo de gasa de seda con adornos de faya y guirnaldas de uvas negras (TRAJE, 1875, p. 145-146).

Junto a trajes de luto riguroso, El Correo de la Moda en 1876 presenta un vestido blanco con cintas negras para el medio luto infantil, "Traje de medio luto para niña de 4 a 8 años", o uno gris con estampados para chica joven, "Traje de medio luto para señorita joven" (Traje de medio luto para señorita joven, El Correo de la Moda, 02/08/1876, p. 232). En la misma publicación vemos la inclusión de piezas de joyería, en madera y azabache, "Aderezo de azabache o madera para luto" (Aderezo de azabache o madera para luto, El Correo de la Moda, 02/08/1876, p. 232) ${ }^{9}$.

El Correo de la Moda en 1877 ilustra la portada del 26 de abril con un figurín de riguroso luto acompañado de sombrero y cofia. La imagen destaca por haber sido dotada de un contexto fúnebre: la dama de espaldas se encuentra en un cementerio, poco habitual este tipo de recursos que enlazan con el gusto romántico imperante (figura 5). El texto especifica los detalles como el uso de cachemir con detalles decorativos de granadina negra, así como la presencia del patrón para realizarlo y las especificaciones técnicas (BALMASEDA, 1877, p. 121). 
Figura 5. Figurín de riguroso luto acompañado de sombrero y cofia - El Correo de la Moda, 26/04/1877

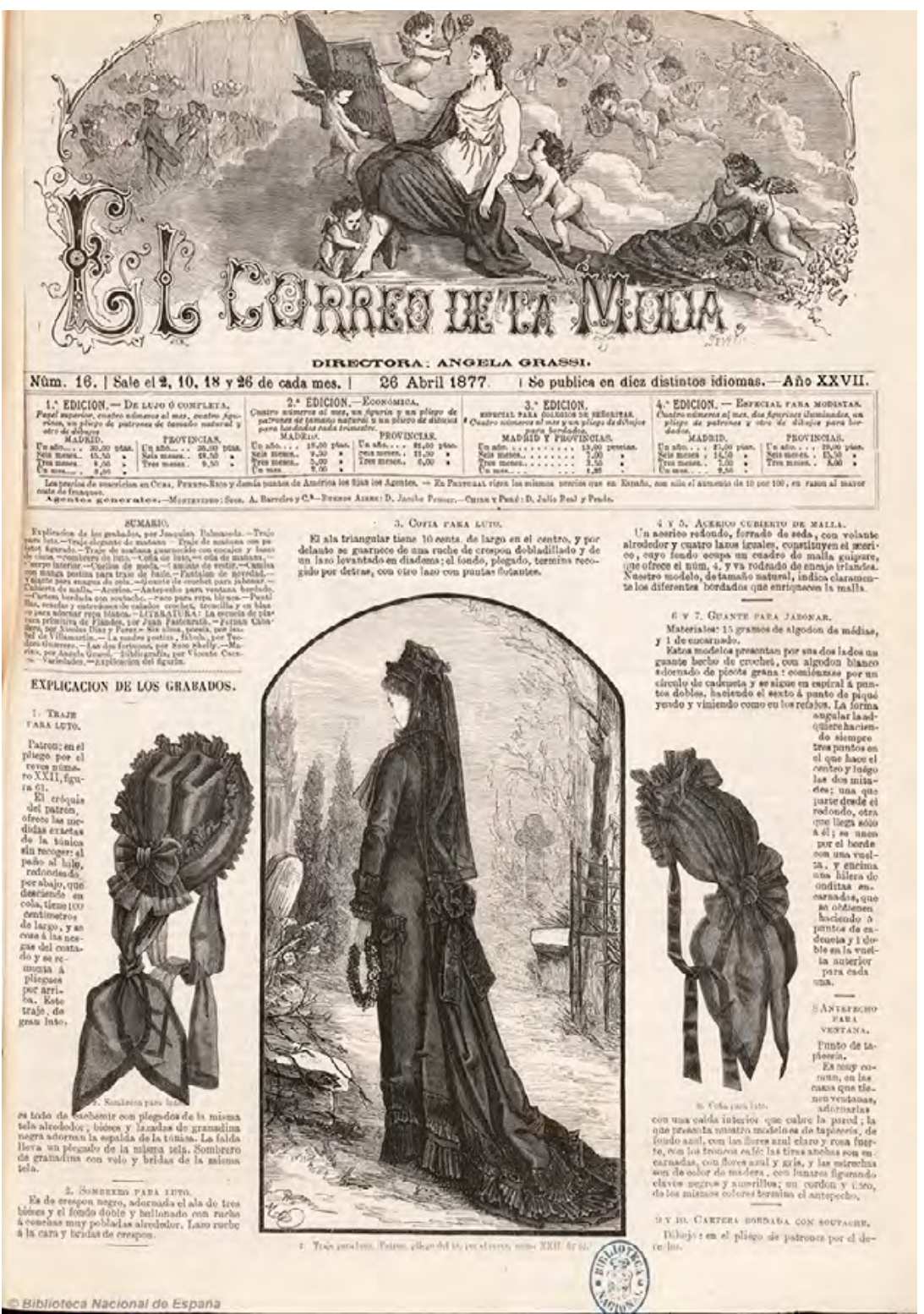

Fonte: EL CORREO DE LA MODA, 26 abr. 1877, p. 121. Fondo de la Biblioteca Nacional de España, (CC BY-SA 4.0).

Entre un grupo de damas hallamos una mujer de luto en la ilustración del 18 de mayo de 1878 en El Correo de la Moda. A doble página, este encuentro al aire libre evoca el paseo en el diferentes modelos se presentan. El luto destaca por cubrir rostro con velo largo. El texto describe la imagen así: "Vestido para luto. Vestido y paletot de cachemir con plegados y bieses de granadina. Sombrero con velo cuadrado de crespón" (BALMASEDA, 1878, p. 146). 
En el mes de julio del mismo año una página se dedica al luto (figura 6). Las ilustraciones de la 16 a la 31 nos muestran tres vestidos, incluyendo uno de niña, y numerosos detalles de cuellos y mangas para medio luto 0 luto riguroso. Se completa con tocas, sombreros y corbatas (EI Correo de la Moda, 02/07/1878, p. 197). La atención a los detalle denota la importancia otorgada a los bordados y acabados para partes del vestido. Se entiende la indumentaria en su totalidad y cada detalle es importante para mantener el concepto de dolor expresado a través de la apariencia. Las revistas son galerías de ideas que pueden ser realizadas gracias a los patrones que se incorporan, siendo en ocasiones autorreferenciales cuando comentan patrones de números anteriores de la misma publicación.

Figura 6. Diferentes modelos y detalles de indumentaria de luto - EI Correo de la Moda, 02/07/1877

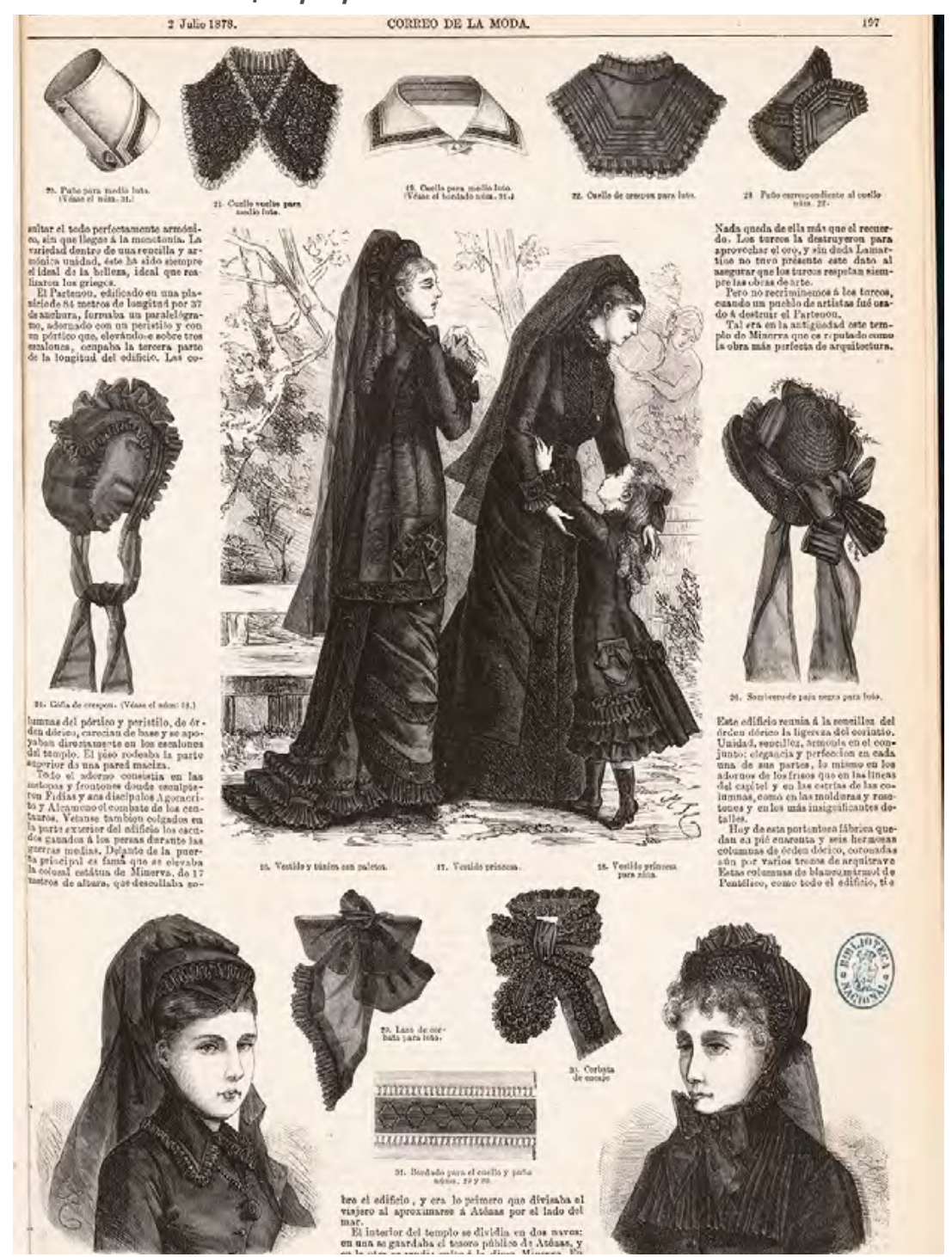

Fonte: EL CORREO DE LA MODA, 2 jul. 1877, p. 197. Fondo de la Biblioteca Nacional de España, (CC BY-SA 4.0). 
Los cambios en la moda tienen su reflejo en las páginas de las revistas, citando a Squicciarino: "la estrecha relación entre las características socioculturales de una época determinada y las correspondientes manifestaciones de la moda" (SQUICCIARINO, 2012, p. 174). La recuperación del polisón (LAVER, 1988, p. 198), sobresaliendo horizontalmente por detrás, para la moda de luto, se hace presente en los años 80 del siglo XIX tal y como podemos ejemplificar con estos dos números de El Correo de la Moda. Cachemir y crespón siguen siendo los tejidos, los drapeados y adornos de granadina se mantienen junto a los velos. El cambio radica en la silueta abullonada propia del periodo con figurines de perfil que lo evidencian. "Traje para luto" y "Manteleta para luto" son las dos propuestas presentadas en mayo de 1886 (HERNANDO, 1886b, p. 156). En octubre del mismo año son 5 los ejemplos presentados, siendo uno de ellos de niña (figura 7). Destaca la especificación de los pouf, para referirse al polisón, que aumentan en tamaño y proyección, manteniendo los drapeados de tela no brillante y la pasamanería en los bieses. Uno de los figurines, "Vestido de crespón y beatilla", añade a la descripción técnica un epiteto sobre su adecuación: "Tiene ya cierta pretensión como para el segundo año de luto, falda plegada y drapeada, y delantal formado por anchos bieses de crespón en diagonal. Cuerpo adornado de los mismos bieses y capota de crespón con velo de gasa" (BALMASEDA, 1886, p. 308-309).

Figura 7. Cinco figurines de indumentaria de luto incluyendo a una niña 30 ] - El Correo de la Moda, 18/10/1886

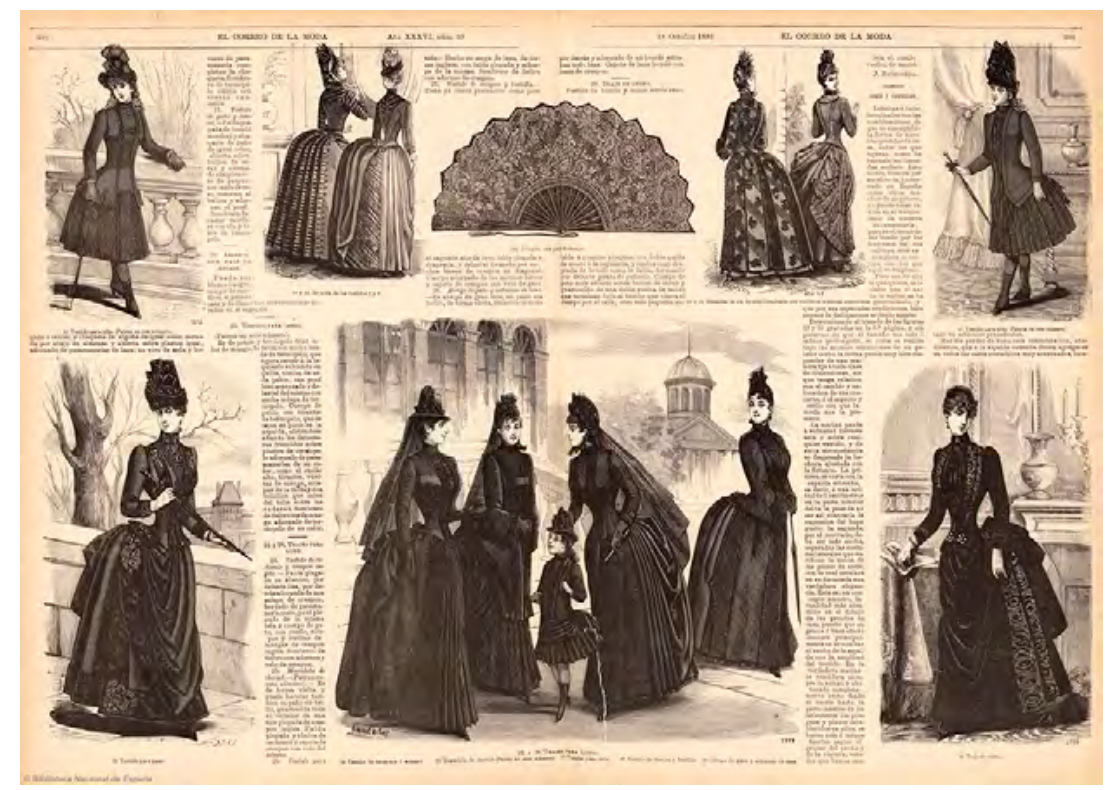

Fonte: EL CORREO DE LA MODA, 18 out. 1886, p. 308-309. Fondo de la Biblioteca Nacional de España, (CC BY-SA 4.0).

En 1890 La Moda Elegante ilustra el número con algunos ejemplos de indumentaria de luto que queremos recuperar. En este número se abarca una panorámica amplia a esta tipología de vestido, haciendo hincapié en los ejemplares de chicas jóvenes. Se ilustran y se describen las siguientes piezas que nos ilustran un outfit adecuado de luto adaptado a la edad (figura 8): 
Figura 8. Figurines de indumentaria de luto para chicas jóvenes - La Moda Elegante, 14/09/1890

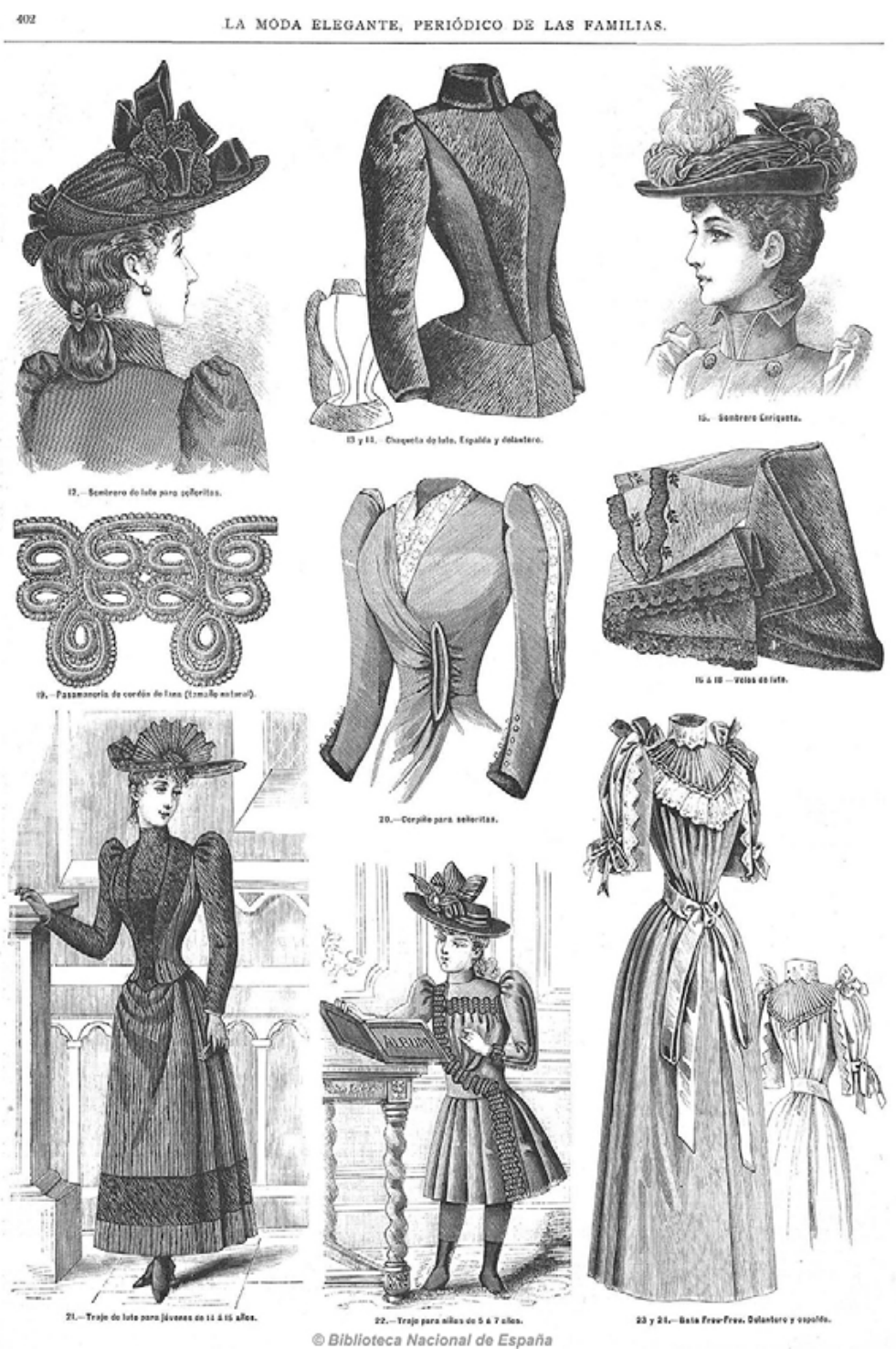

Fonte: LA MODA ELEGANTE, 14 set. 1890, p. 402. Fondo de la Biblioteca Nacional de España, (CC BY-SA 4.0).

Sombrero de luto para señoritas. Núm. 12. Este sombrero va cubierto de crespón plegado y el ala se recorta y se abre en dos vueltas por detrás, cuyo hueco va adornado con un lazo de cinta de terciopelo negro. Por delante, concha de crespón bordado, apuntada con un lazo de cinta de terciopelo negro. Chaqueta de luto. Núms. 13 y 14. Esta chaqueta se hace de cachemir y crespón negros, y se compone de espalda, lados de espalda y de delante, delanteros cerrados en el centro y ajustados con dos pinzas. Aldetas guarnecidas de una tira ancha de crespón; solapas de crespón en la derecha. Cuello alto y enrollado, de crespón. Manga alta de la misma tela. Tela necesaria: un metro de cachemir, de un metro 20 centímetros de ancho; 2 metros 50 centímetros de crespón, y 
4 metros de seda, como forro. Velos de luto. Núms. 16 a 18. Núm. 16. Velo de tul con festón y bordado sobre crespón. Núm. 17. Velo de tul con cenefa de crespón bordado. Núm. 18. Velo de tul con borde de crespón. Traje de luto para jóvenes de 14 a 15 años. Núm. 21.Vestido de velo negro rayado y crespón inglés. Sobre un fondo de falda de alpaca negra, va dispuesta una falda de velo adornada por abajo con una tira ancha de crespón inglés. Corpiño con aldeta recortada en hojas por detrás, y chaleco de crespón abrochado en medio con corchetes bajo dos hileras de botones. Los delanteros, forrados de crespón, se doblan formando solapas. Manga alta de crespón, abrochada por abajo. Cuello de crespón. Sombrero de crespón bordado, cuya ala es de paja negra. Como adorno, un lazo-abanico de crespón (EXPLICACIÓN, 1890, p. 398).

Para luto riguroso de persona adulta, también nos ofrece la revista un modelo (figura 9):

Figura 9. Figurín de luto riguroso de persona adulta - La Moda Elegante, 14/09/1890

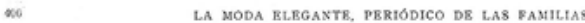

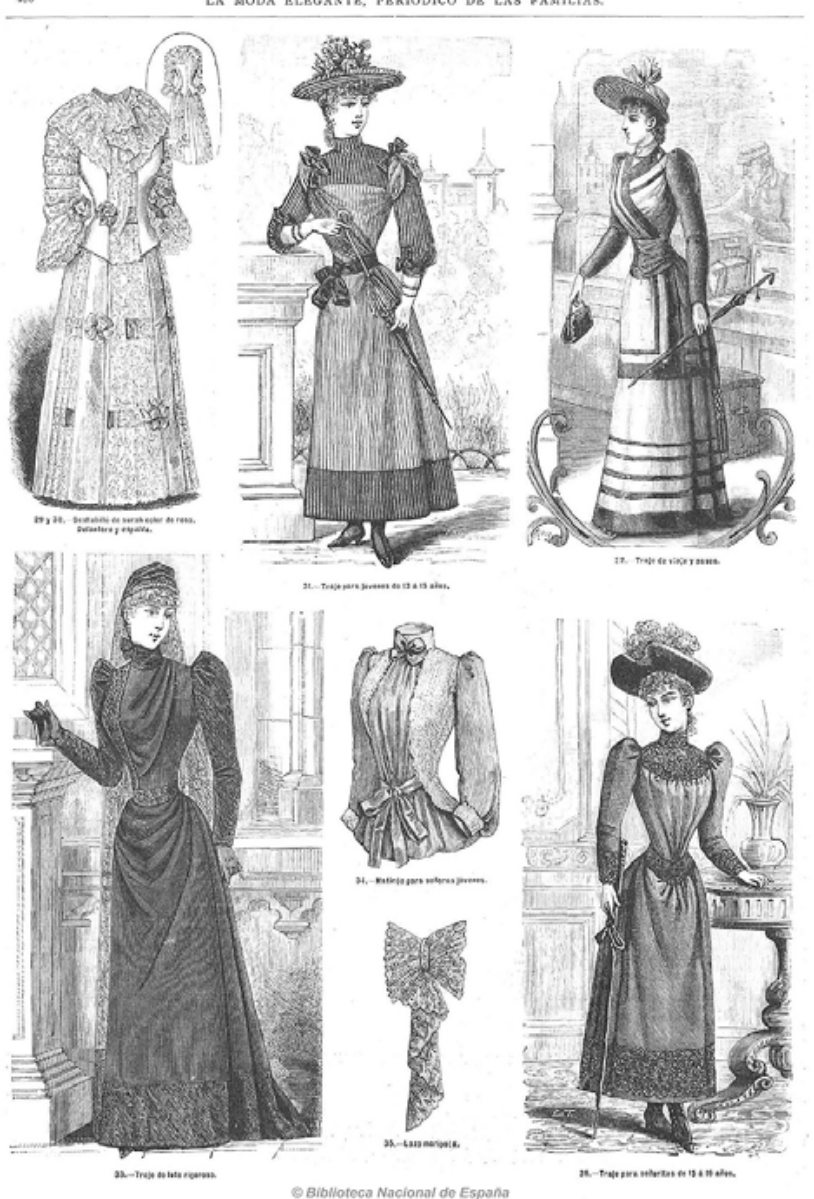

Fonte: LA MODA ELEGANTE, 14 set. 1890, p. 406. Fondo de la Biblioteca Nacional de España, (CC BY-SA 4.0). 
Traje de luto rigoroso. Núm. 33. Vestido de crespón de lana. Sobre un fondo de falda va dispuesta en pliegues la falda de crespón liso, que forma una cola poco prolongada y adornada con una franja de crespón inglés. El corpiño, que es redondo y cuyo cinturón de crespón inglés termina por detrás en dos puntas cruzadas, se abrocha en medio con corchetes bajo una especie de peto plegado, que se estrecha sobre el hombro izquierdo. Manga alta de crespón inglés, plegada por encima. Capota plegada de crespón inglés con un borde estrecho de crespón inglés blanco. Velo largo de crespón que llega hasta el borde de la falda. Guantes negros de piel de Suecia. Zapatos y medias negras (EXPLICACIÓN, 1890, p. 400).

En 1894 encontramos otros ejemplos en la misma publicación, traje de luto para señora y traje de luto para señoritas (La Moda Elegante, 14/02/1894, p. 64-65, il. p. 70). Esta es la tónica general, presentar opciones adaptadas a la edad manteniendo el crespón de lana, el crespón inglés y la lana mate como los tejidos más citados. Los patrones de corpiño y falda reproducen las formas en boga con una atención meticulosa a los volantes, escarapelas, bieses u otras decoraciones que presenten, manteniendo el decoro del propósito luctuoso de las prendas (figura 10). En este mismo número del año 1894, en la sección de respuestas a las lectoras podemos leer una referencia a las po33 ] sibilidades cromáticas: "Para alivio de luto son propios los colores siguientes: negro con cabos blancos, gris y negro, o gris y blanco: también el color malva o violeta. Pasados dos años, el luto de viuda puede aliviarse, y entonces podrá usted usar también el traje de encaje" (ADELA P., 1894, p. 68).

Figura 10. Figurines de trajes de luto para señoras y señoritas - La Moda Elegante, 14/02/1894

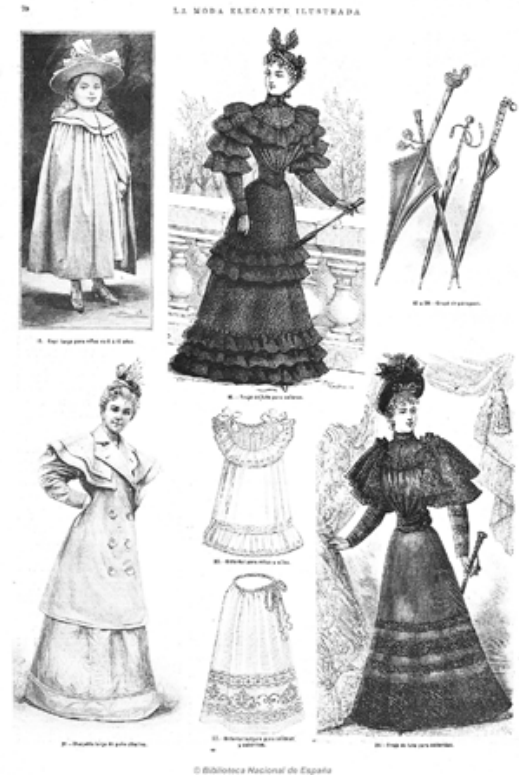

Fonte: LA MODA ELEGANTE, 14 fev. 1894, p. 70. Fondo de la Biblioteca Nacional de España, (CC BY-SA 4.0). 
Estas secciones que atienden las peticiones de las lectoras son las que acostumbran a darnos mayor número de referencias sobre las fórmulas del luto. Tomemos el número del 28 de febrero de 1894, en el que se nos informa sobre aspectos tan variados como la elección de tejidos, de velos, la adecuación a la edad o la limpieza de las prendas:

Con el alivio de luto puede usarse ya el velo de encaje, si usted lo prefiere, y también puede asistirse a todas las diversiones: teatro, comida, paseos, reuniones, etc. [...] Para limpiar la ropa negra de luto, se pone a hervir un puñado de hojas de higuera en dos litros de agua; se deja reducir a la mitad, y una vez caliente se frota con una esponja empapada en este líquido la ropa que ha de limpiarse (ADELA P., 1894, p. 92-93).

La prensa no especializada en moda también se hace eco de la codificación del luto. En La Vanguardia para el año 1897, así se mostraba la nueva influencia inglesa introduciendo collares blancos a los vestidos negros más tradicionales:

Publicamos hoy los últimos figurines de Paris para trajes de luto en los que, como se observará, se introduce la costumbre inglesa de llevar cuellos y puños blancos, aún en casos de luto para viudas, en vez de ser los trajes completamente negros como sucedía veinte años atrás. El figurin número 5 representa un traje de luto riguroso, así como el número 3 , en los que domina el crespón, habiéndose introducido en este último una modificación en el velo. Los figurines números 1 y 4 representan trajes de luto de alivio para visita, notables por su elegancia y novedad, mientras que los figurines números a y 6 son para trajes de interior. El número 2 es de medio luto, y el número 6 , propio más bien para recepción, resulta de la mayor novedad y se compone de falda lisa en la delantera y con algunos pliegues a los lados, con cuerpo ajustado y un gran lazo blanco en el cuello (LA MODA, 1897, p. 4).

Desde un punto de vista comercial y económico, las nuevas tiendas especializadas y las secciones de los grandes almacenes empiezan a estar presentes en la publicidad de los diarios y gacetas. Se observa en prensa el cambio producido en la producción de la indumentaria y el acceso a las novedades seriadas que modifican los patrones de consumo anteriores. En La Vanguardia se anuncian los Grandes Almacenes El Siglo, que estaban en el número 5 de la barcelonesa Rambla ${ }^{10}$. Nos ofrecen en 24 horas trajes a medida de entretiempo por 8 duros, y en relación a nuestra investigación "Trajes negros para luto desde 10 duros" (La Vanguardia, 21/08/1882, p. 5310). 
Los mismos almacenes barceloneses en 1887 ofrecen entre sus confecciones, sedería, lanería, guantería, perfumería, géneros de punto, batería de cocina, paraguas, sombrillas y abanicos, una nueva "sección de lutos y alivios". Nos dice el texto:

Y por último, nos complacemos en comunicar a nuestras distin-
guidas parroquianas que, correspondiendo a sus indicaciones,
hemos dado nueva organización a parte a la importantísima
sección de lutos y alivios en la cual estamos seguros de ofre-
cer delicadísimas especialidades, sin competencia posible por su
buen gusto y baratura (GRANDES ALMACENES EL SIGLO, 1887,
p. 7087).

El coste económico y el ahorro han sido elementos que la publicidad ha remarcado. Leíamos el concepto baratura en el extracto anterior, y los mismos almacenes en 1890 presentan una "verdadera ocasión gran rebaja de precios solo durante 22 días" que se traduce en un 5\% de descuento en la sección de luto:

Como fin de estación, los dueños de los Grandes Almacenes de El Siglo ofrecen a su numerosa clientela y al público en general, una gran rebaja de precios en todos los géneros que quedan existentes de la estación de verano a la vez que un pequeño descuento en todos los demás artículos que se expenden en el Establecimiento (GRANDES ALMACENES EL SIGLO, 1890).

Con la entrada en el siglo XX, algunos negocios se habian especializado en las prendas de luto, como es el caso de Modas de Casa Adler en Barcelona. Con un 26\% de descuento en 1915, ofrecían "sombreros para señoras y niñas [...] especialidad en lutos" (CASA ADLER, 1915, p. 18). En el mismo año en Madrid, La Villa de París hace un aviso: "Esta casa ha establecido recientemente una sección especial para lutos, con gran surtido de vestidos en todas sus tallas, así como también blusas y faldas sueltas para servir en el acto" (LA VILLA DE PARIS, 1915). Un ejemplo más de la inclusión del luto como sección comercial en las boutiques y grandes almacenes.

En el siglo XX nos alejamos de las formas sociales protocolarias de enfrentarse a la muerte. A medida que avanza el siglo se modifican los códigos y la rigidez en la etiqueta. Vestir de negro y con corrección será la norma adoptada y una vez finalizado el conflicto de la Segunda Guerra Mundial y ya en plena segunda mitad del siglo XX, el luto empezará a disolverse en la cultura occidental hasta llegar a nuestros días.

Recebido: $12-10-2018$

Aprovado: 23-11-2018 


\section{NOTAS}

${ }^{1}$ Este tema del luto hispánico a lo largo de los diferentes periodos ha formado parte de las investigaciones presentadas por el autor en encuentros internacionales en los últimos años: "Dressing the Soul: Mourning Regulation and Excess in Spanish Culture" en Costume Colloquium V: "Restraint and Excess in Fashion and Dress" (Florencia, 17-20 de noviembre 2016) y "La indumentaria de luto en España. La codificación del dolor entre los siglos XVI y XX" en el XVII Congreso de la Asociación Española de Semiótica y I Congreso de la Asociación Ibérica de Semiótica: "Modas, modos, maneras" (Lisboa, 23-25 de noviembre de 2017).

2 Pintado en Roma y concluido en Madrid, según testimonia su firma, fue distinguido con un certificado de segunda medalla en la exposición Nacional de 1887, adquiriéndolo el Estado por un alto precio, debido sin duda a lo emblemático de su argumento tras dos años del fallecimiento del monarca. Se puede consultar la obra en este enlace: https://www.museodelprado.es/coleccion/obra-de-arte/muerte-de-don-alfonsoxii-el-ultimo-beso/6cf3b00f-9283-44a0-9870-cfbb74289c7d?searchid=4cfc3e8c-4364-6fb9-742f769253 c0c238

${ }^{3}$ Se puede consultar la obra en este enlace: https://www.museodelprado.es/coleccion/obra-de-arte/mariacristina-de-habsburgo-lorena/30c90bb3-ba4f-416e-875b-7a9b2b764046

${ }^{4}$ Se pueden consultar las obras en estos enlaces: https://www.racba.org/mostrarobra2.php?id=245 y https://www.museunacional.cat/es/colleccio/estudio-para-retrato-de-la-reina-regente-maria-cristina-dehabsburgo/antoni-caba/010643-000

${ }^{5}$ Se puede consultar la obra en este enlace: https://www.museodelprado.es/coleccion/obra-de-arte/mariacristina-de-habsburgo-con-su-hijo-alfonso/330c05a4-e9b9-4834-ae1e-a22e520e9bc9?searchid=97519452c820-648b-7cfb-5ce698165ea6

${ }^{6}$ Muchas de las reglas del luto victoriano se pueden aplicar a la sociedad española de finales del siglo XIX. A través de las publicaciones inglesas y francesas la sociedad ibérica se hacía eco de la moda luctuosa y se observa como algunas de las pautas que describe Lou Taylor en sus estudios sobre la sociedad victoriana y americana se pueden encontrar en la española tal y como desarrollamos en este artículo.

${ }^{7}$ En España la década de los años veinte y treinta del siglo XIX marca el inicio de la prensa de moda con la aparición del Periódico de las Damas, El Correo de las Damas y posteriormente La Moda Elegante, inspiradas en las publicaciones francesas del momento, pero el verdadero estallido se produjo en la segunda mitad del siglo XIX con la publicación de unas dieciocho revistas relacionadas, de una forma u otra, con la moda.

${ }^{8}$ Novenario se refiere al periodo de nueve días que se emplea en los pésames, lutos y devociones entre los parientes inmediatos de un difunto. También designa los sufragios y exequias celebrados el noveno día después de la muerte de un ser querido.

9 Joyería de luto encontramos conservada en diferentes museos como serían el Museo Romántico de Madrid o el Museo del Traje. A la madera negra y al azabache, añadimos ebonita o cabello humano, para la realización de piezas en el periodo romántico. El azabache, de procedencia inglesa, era una materia prima cara. Las limitaciones que ofrece este material, un carbón fósil, desaparecieron gracias a la intervención de las nuevas materias plásticas naturales desarrolladas durante el siglo XIX. La ebonita o vulcanita, una mezcla de caucho, azufre y aceite de linaza, se adaptó rápidamente a la fabricación con molde de piezas de joyeria. El cabello humano trenzado permite conservar en brazaletes o broches la presencia del que está ya ausente.

${ }^{10}$ Los Almacenes El Siglo fueron unos grandes almacenes populares, situados en las Ramblas de Barcelona desde 1881 hasta 1932 después de que un colosal incendio destruyera el edificio. En la tienda, almacenes y otros departamentos de los grandes almacenes, trabajaban 1.050 empleados, a los que había que sumar otras 600 personas que trabajaban en distintos talleres de confección, que elaboraban los productos para El Siglo. Editaban 30.000 catálogos, y repartían unos 90.000 globos al año entre sus clientes para alegría de sus hijos. Poseían una flota de 25 camiones para efectuar el reparto a domicilio de sus productos.

\section{REFERÊNCIAS}

ADELA P. Correspondencia particular. La Moda Elegante, Cádiz, 14 fev. 1894

BALMASEDA, Joaquina. Explicación de los grabados. El Correo de la Moda, Madrid, 26 abr. 1877.

BALMASEDA, Joaquina. Explicación de los grabados. El Correo de la Moda, Madrid, 15 maio 1878.

BALMASEDA, Joaquina. Explicación de los grabados. El Correo de la Moda, Madrid, 18 out. 1886.

CALVO POYATO, José. Reinas viudas de España. Barcelona: Península, 2002.

CASA ADLER. Publicidad. La Vanguardia. Barcelona, 5 fev. 1915.

CORRESPONDENCIA. El Correo de la Moda. Madrid, 10 nov. 1876.

DI NOLA, Alfonso. La negra señora: antropología de la muerte y el luto. Barcelona: Belacqua, 2006.

EXPLICACIÓN de los grabados. La Moda Elegante, Cádiz, 14 set. 1890. 
FLÜGEL, John Carl. Psicología del vestido. Barcelona: Melusina, 2015.

GARCÍA BARRANCO, Margarita. La reina viuda o la muerte del cuerpo simbólico. Chronica Nova, $n$. 34, p. 45-61, 2008.

GÓMEZ SANCHO, Marcos. La pérdida de un ser querido. El duelo y el luto. Madrid: Arán, 2007.

GONZÁLEZ DÍEZ, Paula; PÉREZ CUADRADO, Pedro. La Moda Elegante y El Correo de las Damas, dos publicaciones especializadas en moda en el siglo XIX. Doxa.comunicación, n. 8, p. 53-71, 2009.

GRANDES ALMACENES EL SIGLO. Publicidad. La Vanguardia, Barcelona, 11 nov. 1887.

GRANDES ALMACENES EL SIGLO. Publicidad. La Vanguardia, Barcelona, 15 ago. 1890.

HALKA, Mario. Prácticas sociales. La Moda Elegante, Cádiz, 30 maio 1885.

HERNANDO, Cesáreo. Revista de modas. El Correo de la Moda, Madrid, 2 dez. 1886a.

HERNANDO, Cesáreo. Explicación de los grabados. El Correo de la Moda, Madrid, 26 maio $1886 b$.

LA MODA en Paris: trajes de luto. La Vanguardia, Barcelona. 29 jan. 1897.

LA VILLA DE PARÍS. Publicidad. ABC, Madrid, 1 jan. 1915.

LAVER, James. Breve historia del traje y la moda. Madrid: Cátedra, 1988.

LLORENTE, Mercedes. Imagen y autoridad en una regència: Ios retratos de Mariana de Austria y los límites del poder. Studia Histórica. Historia Moderna, n. 28, p. 211-238, 2006.

LOS FUNERALES de S. M. el rey D. Alfonso XII. La llustración Española y Americana, Madrid, 8 dez. 1885.

MARQUÉS DE VALLE-ALEGRE Crónica de Madrid. La Moda Elegante, Cádiz, 6 dez. 1885.

MARTÍNEZ-BURGOS, Palma. Viudas ejemplares. La princesa Doña Juana de Austria, mecenazgo y devoción. Chronica Nova, n. 34, p. 63-89, 2008.

ORTIZ GARCíA, José A. Reines mortes o la mort en femení. El funeral reial en la Barcelona dels segles XVII i XVIII. Emblecat, revista de l'Associació Catalana d'Estudis d'Emblemàtica. Art i societat, n. 2, p. 115-125, 2013.

ROSAURA. Una plana per les senyores. La II-lustració Catalana, Barcelona, 24 dez. 1905.

SOUICCIARINO, Nicola. EI Vestido habla: consideraciones psico-sociológicas sobre la indumentaria. Madrid: Cátedra, 2012.

TAYLOR, Lou. Mourning Dress: A Costume and Social History. Oxford: Routledge, 2009.

TAYLOR, Lou. Mourning dress. In: STEELE, Valerie (org.). The Berg Companion to fashion. Oxford: Berg Publishers, 2010. p. 518-520.

VARELA, Javier. La Muerte del Rey. El ceremonial funerario de la monarquía española (1500-1885). Madrid:Turner, 1990.

VIZCONDESA DE CASTELFIDO. Revista de Modas. La Moda Elegante, Cádiz, 14 jul. 1870. VIZCONDESA DE CASTELFIDO. Revista Parisiense. La Moda Elegante, Cádiz, 22 nov. 1889.

TRAJE para alivio de luto. La Moda Elegante, Cádiz, 22 maio 1875. 